\section{Can we predict the presence of teratoma in the retroperitoneum before post-chemotherapy retroperitoneal lymphadenectomy?}

Djordje Argirovic ${ }^{1}$, Aleksandar Argirovic ${ }^{2}$

${ }^{1}$ Clinic of Urology, CCS, Oupatient Clinic „Argirović“,

Urology, Belgrade, Serbia

${ }^{2}$ Clinical Hospital Center ,Zemun-Belgrade“,

Department of Urology, Zemun. Serbia

\section{Da li možemo predvideti prisustvo teratoma u retroperitoneumu pre post-hemioterapijske retroperitonealne limfadenektomije?}

\author{
Đorđe Argirović ${ }^{1}$, Aleksandar Argirović ${ }^{2}$ \\ ${ }^{1}$ Urološka klinika, KCS, Poliklinika „Argirović“, \\ Urologija, Beograd, Srbija \\ ${ }^{2}$ Kliničko Bolnički Centar „Zemun-Beograd“, \\ Služba urologije, Zemun, Srbija
}

\section{Abstract}

The biological potential of teratoma remains unpredictable, therefore identifying its presence in the retroperitoneum remains important. We evaluated patients undergoing post-chemothe rapy retroperitoneal lymphadenectomy (PC-RPLA) for nonseminomatous testicular tumors (NSTT), to determine predictors of teratomatous elements in the retroperitoneum. We identified 161 patients from 1982 to 2005 who underwent PC-RPLA for metastatic NSTT. Multiple clinical and pathological variables were reviewed from out RPLA database. Of the 161 patients in our series, $112(70 \%)$ received only induction chemotherapy and $49(30 \%)$ required 2nd line chemotherapy. Studies of retroperitoneal pathology demonstrated the presence of fibrosis in $44(27 \%)$, teratoma in $82(51 \%)$ and vital carcinoma in $35(22 \%)$.Among 82 patients $(51 \%)$ with finding of teratomatous elements at PC-RPLA, we revealed the presence ofmature teratoma in $85 \%$, immature teratoma in $12 \%$ and teratoma with malignant transformation in $3 \%$. Of the 99 patients $(61 \%)$ with teratomatous elements in the primary NSTT, $61(62 \%)$ had teratoma at PC-RPLA. Even in the absence of teratoma in the primary NSTT, teratoma was present in the retroperitoneum in 21 of 62 patients $(32 \%)(\mathrm{p}<0.0001)$. All patients had normal values of serum tumor markers (STM) at PC-RPLA. Post-chemotherapy retroperitoneal residual mass measuring $<2 \mathrm{~cm}$, from $2.1-5.0 \mathrm{~cm}$ and $>5 \mathrm{~cm}$ in diameter occured in 30\%, 52\% and 55\%, respectively. By multivariate analysis, teratoma in the orchiectomy specimen $(\mathrm{p}<0.005)$, relative change in nodal size before and after chemotherapy $(p<0.005)$, and no requirement for 2 nd line chemotherapy $(p=0.33)$ were independent predictors for the presence of the teratoma in the retroperitoneum. Teratoma remains

\section{Apstrakt}

Biološki potencijal teratoma je nepredvidljiv, i iz tog razloga indentifikacija njegovog prisustva $u$ retroperitoneumu je od izuzetnog značaja. Analizirani su pacijenti podvrgnuti posthemioterapijskoj retroperitonealnoj limfadenektomiji (PH-RPLA) zbog neseminomskih tumora testisa (NSTT) da bi odredili prediktivne elemente za nalaz teratoma u retroperitoneumu. Indentifikovali smo 161 pacijenta u periodu od 1982 do 2005 podvrgnutih PH-RPLA zbog metastatskih NSTT. Brojne kliničke i patološke varijable su analizirane u našoj RPLAbazi podataka.Od 161 pacijenta u našoj seriji, 112 (70\%) je primilo samo indukcionu hemioterapiju, dok je 49 (30\%)iziskivalo hemioterapiju druge linije. Analiza retroperitonealne histopatologije je pokazala prisustvo fibroze kod 44 (27\%) pacijenata, teratoma kod $82(55 \%)$ i vitalnog karcinoma kod 35 (22\%) pacijenata. Od 82 pacijenta (51\%) sa nalazom teratomskih elemenata na $\mathrm{PH}-$ RPLA, konstatovali smo prisustvo zrelog teratoma u $85 \%$, nezrelog teratoma u $12 \%$ i teratoma sa malignom transformacijom u $3 \%$. Od 99 pacijenata $(62 \%)$ sa teratomskim elementima $u$ primarnom NSTT, 61 (62\%) je imalo teratom na PH-RPLA. Čak i u odsustvu teratoma u primarnom NSTT, teratom je bio prisutan kod 21 od 62 pacijenta $(34 \%)(p<0.0001)$. Svi pacijenti su imali normalne vrednosti serumskih tumorskih markera na PH-RPLA. Posthemioterapijska retroperitonealna rezidualna masa dijametra $<2 \mathrm{~cm}$, od 2.1-5.0 cm, i $>5.0 \mathrm{~cm}$ je postojala kod $30 \%$, $52 \%$ i $55 \%$ pacijenata. Multivarijantna analiza je pokazalada su prisustvo teratoma u primarnom tumoru testisa $(p<0.005)$, relativna promena nodalne veličine pre i posle hemioterapije $(\mathrm{p}<0.005)$, i odsustvo potrebe za hemioterapijom druge linije $(\mathrm{p}=0.03)$, bili nezavisni prediktivni faktori za prisustvo teratoma $\mathrm{u}$ retroperitoneumu. Teratom predstavlja čest histološki 
a common histologic finding in the retroperitoneal lymph nodes following chemotherapy. We have identified several pre-RPLA variables that predict the finding of teratoma in the retroperitoneum for men treated with chemotherapy for metastatic NSTT.

Key words: testis, tumors, nonseminomatous, teratoma, chemotherapy, retroperitoneal lymphadenectomy. nalaz u retroperitonealnim limfnim žljezdama posle hemioterapije. Indentifikovano je više varijabli preRPLA, koje su bile prediktivne za nalaz teratoma $\mathrm{u}$ retroperitoneumu kod muškaraca tretiranih sa hemioterapijom zbog metastatskog NSTT.

Ključne reči: testis, tumori, neseminomski, teratom, hemioterapija, retroperitonealna limfadenektomija.

\section{Introduction}

The appropriate integration of chemotherapy and surgery for the mnagement of NSTT has resulted in overall survival rates greater than $90 \%{ }^{1}$. Although testicular cancer is highly curable it requires appropriate management at all stages ${ }^{2}$. Inappropriate management increases the morbidity, mortality and the burden of therapy for the patient 3,4 .

PC-RPLA is an integral component in the management of advanced NSTT. Following induction chemotherapy approximately $40 \%$ of patients undergoing RPLA will have teratoma in the retroperitoneum, and an additional $10 \%$ to $15 \%$ will have viable cancer ${ }^{5,6}$. Teratoma is chemorefractory, and has an unpredictable biological potential with the possibility of growth, invasion of adjacent organs, and devastating late relapse if not completely resected ${ }^{7-10}$.

Since almost $27 \%$ of resected retroperitoneal specimens have only fibrosis (in the present series $22 \%$ ), a number of investigators have attemped to reliable predict for itspresence preoperatively and, thus spare this subset of patients the associated morbidity of post-chemotherapy surgery. Several investigators have reported that even with normal post-chemotherapy CT and no teratoma in the primary tumor, approximately $20 \%$ to $30 \%$ of patients will harbor teratoma and viable malignancy ${ }^{11,12}$. However, our study demonstrated that a patient obtaining a CR after 1st line chemotherapy can be safely observed without PC-RPLA. Relapses are rare and potentially curable with further therapy ${ }^{13}$. Currently predictive models and imaging modalities cannot reliably predict the finding of fibrosis at PC-RPLA. Despite this limitation a number of investigators continue to base the decision to perform PC-RPLA on residual mass size alone, omitting PC-RPLA in patients with residual mass of $1 \mathrm{~cm}$ or less ${ }^{14}$. We evaluated men undergoing PC-RPLA for metastatic NSTT at our institution to identify preoperative variables that may predict the histological finding of teratoma in the retroperitoneum.

Until now, there is no safe or medically justified method of male contraception. In case of normal spermatogenesis, a normal production and secretion of the pituitary gonadotropins, FSH and LH are required. Inhibition of production and release of gonadotropins (releasing hormone analogues) can lead to severe forms of oligospermia or azoospermia, and to the castration syndrome. Application of testosterone at a dose of $200 \mathrm{mg}$ a week for 12 weeks can lead to reversible restraint in the secretion of FSH and LH and associated oligospermia, but as it is not a phenomenon of all men, this method is not an effective contraceptive method ${ }^{4}$.

Sterilization is a method of contraception by which a person (a woman or a man), permanently revoke the ability of fertilization. Sterilization in the modern world is becoming one of the leading methods. Sterilization is a personal right of every person and can be done only at the request of individuals. In our country, the issue of sterilization is still not legally regulated. It is performed only with certain medical indications: severe and incurable mental conditions and disorders such as schizophrenia, cretinism, severe birth defects and heart disease, chronic leukemia, severe forms of diabetes and severe renal disease as well as Rh sensitization women.

Female sterilization is performed by interrupting the continuity of the fallopian tubes and can be done in several ways, by different surgical techniques. Tubal occlusion is achieved by binding, cutting, unipolar or bipolar cauterization, placing mechanical means into the pulp chamber of the uterus or fallopian tube, tubal ligation and others. 
Male sterilization ( vasectomy ) is performed as an interruption of the flow of the vas deferens (vas deferens). Unlike women, sterilized men are not infertile immidiately because it takes certain time to empty the urethral canal. It is necessary to establish a control of semen after ten ejaculations.

Finally, it is important to emphasize that the use of any contraceptive method is better than haphazard exposure to the risk of unwanted pregnancy.

\section{Material and Methods}

From 1982 to 2005 a total of 161 patients underwent PC-RPLA for metastatic NSTT following induction or $2^{\text {nd }}$ line chemotherapy in our institutions. All patients were treated with chemotherapy for metastatic NSTT at initial presentation and subsequently underwent PC-RPLA. Patient undergoing extra-retroperitoneal surgery were not included in this study because our previous analysisdemonstrated that these patients may be at risk of progression independently of tumor histology ${ }^{4}$.

Clinical and pathological data were obtained from our prospective surgical database. A logistic regression model was constructed to evaluate variables that may predict for teratomatous elements in the retroperitoneum. Cases with the presence of mature, immature, or teratoma with malignant transformation in the resected specimen were classified as positive for teratomatous elements. Tumor markers values and retroperitoneal nodal size was documented before and after chemotherapy. The IGCCCG risk classification was determined based on the standardized criteria before induction chemotherapy, and ealuated in our multivariate analysis by grouping patients with intermediate and poor risk disease together. Chemotherapy regimens were documented, and cases were classified as requiring induction chemotherapy alone or $2^{\text {nd }}$ line therapy. Statistical analysis was performed using STATA R 8.2 software, with $p<0.05$ considered statistically significant and odds ratio with $95 \%$ confidence intervals (CI) reported for our logistic regression model.

\section{Results}

Primary tumor histology in men undergoing PC-RPLA consisted of embryonal cell carcinoma in $71 \%$, seminomatous elements in $22 \%$, choriocarcinomatous elements in $2 \%$ and teratomatous elements in $61 \%$ (Table 1.)

\begin{tabular}{|l|l|}
\hline HISTOLOGY & NO. OF PATIENTS (\%) \\
\hline Embryonal cell carcinoma & $115(71)$ \\
\hline Seminomatous elements & $35(22)$ \\
\hline Choriocarcinomatous elements & $13(8)$ \\
\hline Yolk sac elements & $5(3)$ \\
\hline Teratomatous elements & $99(61)$ \\
\hline
\end{tabular}

Table 1. Primary tumor histology in men undergoing PC-RPLA

Retroperitoneal hystology at PC-RPLA demonstrated the presence of fibrosis in 44 (27\%), teratoma in 82 (51\%) and viable cancer in 35 (22\%) patient submitted to PC-RPLA. The vaste majority of patients presented with bulky abdominal metastatic disease $(59 \%, 74 \%$ and $66 \%$, respectively) before PC-RPLA. Among 82 patients $(51 \%)$ with finding of teratomatous elements at PC-RPLA we revealed the presence of mature teratoma in $85 \%$, immature teratoma in $12 \%$ and teratoma with malignant transformation in $3 \%$ (Table 2.).

MATERIA MEDICA • Vol. $31 \cdot$ No. $1 \bullet$ januar 2015. 


\begin{tabular}{|c|c|c|c|}
\hline & $\begin{array}{l}\text { FIBROSIS } \\
\text { No. pts (\%) }\end{array}$ & $\begin{array}{l}\text { TERATOMA } \\
\text { No.pts (\%) }\end{array}$ & $\begin{array}{l}\text { VIABLE GCT } \\
\text { No. pts }(\%)\end{array}$ \\
\hline Total pts & $44(27)$ & $82(51)$ & $35(22)$ \\
\hline \multicolumn{4}{|c|}{ Node cm (No): } \\
\hline$\leq 2(23)$ & $11(48)$ & $7(30)$ & $5(22)$ \\
\hline $2.1-5(29)$ & $7(24)$ & $15(52)$ & $7(24)$ \\
\hline$>5(109)$ & $26(24)$ & $60(55)$ & $23(21)$ \\
\hline
\end{tabular}

Table 2. Distribution of retroperitoneal histology for men undergoing PC-RPLA.

All patients had normal values of STM at PC-RPLA. Good vs intermediate/poor IGCCCG risk criteria occured in relation of $56 \%$ vs $41 \%$. Of 99 patients (61\%) with teratomatous elements in the primary tumor, $61(62 \%)$ had teratoma at PC-RPLA, whereas in the absence of teratoma in he primary tumor, teratoma was present in the retroperitoneum in $21(34 \%)$ of 62 patients $(\mathrm{p}<0.0001)$. Of the 161 patients in our series, 112 (70\%) received only induction chemotherapy and 49 (30\%) required 2 nd line chemotherapy. Post-chemotherapy retroperitoneal residual mass size measuring $<2 \mathrm{~cm}$, from $2.1-5.0 \mathrm{~cm}$ and $>5 \mathrm{~cm}$ in diameter occured in $8 \%$, $18 \%$ and $74 \%$, respectively. Patients with no change or increasing retroperitoneal nodal size and those with smaller reduction in nodal size following chemotherapy were significantly more likely to have teratoma in the retroperitoneal resected specimen.

Table 3. demonstrate incidence of teratoma in the retroperitoneum according to IGCCCG risk classification, primary tumor histology, residual nodal size and percent reduction in retroperitoneal nodal size.

\begin{tabular}{|l|l|l|}
\hline VARIABLES & NO. PTS (\%) & $\begin{array}{l}\text { NO. OF TERATOMATOUS } \\
\text { ELEMENTS IN RP (\%) }\end{array}$ \\
\hline IGCCCG risk classification & & \\
\hline Good & $96(60)$ & $55(57)$ \\
\hline Intermediate/poor & $65(40)$ & $27(41)$ \\
\hline Teratoma in orchiectomy specimen & & $61(62)$ \\
\hline Yes & $99(61)$ & $21(34)$ \\
\hline No & $62(39)$ & $67(60)$ \\
\hline Induction chemotherapy & $112(70)$ & $15(31)$ \\
\hline $2^{\text {nd }}$ line chemotherapy & $49(30)$ & \\
\hline RP node cm after chemotherapy & & $7(30)$ \\
\hline$\leq 2$ & $23(14)$ & $15(52)$ \\
\hline $2.1-5$ & $29(18)$ & $60(55)$ \\
\hline$>5$ & $109(68)$ & \\
\hline
\end{tabular}




\begin{tabular}{|l|l|l|}
\hline Reduction in RP node size & & \\
\hline No change & $14(9)$ & $4(29)$ \\
\hline $90 \%$ or greater & $15(9)$ & $7(47)$ \\
\hline $90 \%-50 \%$ & $65(40)$ & $22(34)$ \\
\hline $50 \%-0 \%$ & $60(31)$ & $33(66)$ \\
\hline Enlarging RP node size & $17(11)$ & $16(94)$ \\
\hline
\end{tabular}

Table 3. Incidence of teratoma in the retroperitoneum in men undergoing PC-RPLA

Before analyzing data we specified a single multivariate model which included nodal size before and after chemotherapy as 2 independent factors. Table 4. contains the results from this model.

\begin{tabular}{|l|l|l|l|}
\hline VARIABLES & ODDS RATIO & $\mathbf{9 5 \%}$ CI & $\mathbf{p}$ \\
\hline IGCCCG good risk group & 0.61 & $0.35-1.08$ & 0.089 \\
\hline Orchiectomy histology: & & & \\
\hline Seminoma & 0.95 & $0.59-1.58$ & 0.8 \\
\hline Embryonal & 1.41 & $0.80-2.50$ & 0.2 \\
\hline Teratoma & 3.31 & $2.11-5.21$ & $<0.005$ \\
\hline $2^{\text {nd }}$ line chemotherapy & 0.51 & $0.26-1.00$ & 0.048 \\
\hline RP node cm before chemotherapy & 0.77 & $0.70-0.85$ & $<0.005$ \\
\hline RP node cm after chemotherapy & 1.60 & $1.40-1.83$ & $<0.005$ \\
\hline
\end{tabular}

Table 4. Multivariate model predicting teratoma at PC-RPLA

These results suggested that relative change in nodal size before and after chemotherapy is a better predictor than absolute change. Therefore, we analyzed these data with relative change in nodal size before and after chemotherapy in the model. Relative change in nodal size before and after chemotherapy was calculated by dividing post-chemotherapy nodal size by pre-chemotherapy nodal size and analyzing as continous variable. To evaluate the quality of the model we calculated the AUC and validated our results using boot-straping model. The uncorected AUC for our logistic regression model was 0.821 and the corrected AUC indicates that our model selection was appropriate.

By multivariate analysis, teratoma compound in the orchiectomy specimen $(\mathrm{p}<0.005)$, relative change in nodal size before and after chemotherapy $(\mathrm{p}<0.005)$, and no requirement for salvage chemotherapy $(\mathrm{p}=0.03)$ were statistically significant predictors of the presence of teratoma in the retroperitoneum (Table 5.). While IGCCCG risk classification was not a statistically significant predictor of teratoma in the retroperitoneum, there was a trend $(\mathrm{p}=0.093)$ with intermediate and poor risk patients having a higher probability of retroperitoneal teratoma at PC-RPLA. 


\begin{tabular}{|l|l|l|l|}
\hline VARIABLES & ODDS RATIO & $\mathbf{9 5 \%}$ CI & $\mathbf{p}$ \\
\hline IGCCCG good risk group & 0.62 & $0.35-1.08$ & 0.093 \\
\hline Orchiectomy histology: & & & \\
\hline Seminoma & 1.14 & $0.69-1.87$ & 0.6 \\
\hline Embryonal & 1.43 & $0.82-2.52$ & 0.2 \\
\hline Teratoma & 3.04 & $1.90-4.85$ & $<0.0005$ \\
\hline $2^{\text {nd }}$ line chemotherapy & 0.48 & $0.25-0.93$ & 0.03 \\
\hline RP node cm before chemotherapy & 1.02 & $0.95-1.08$ & 0.7 \\
\hline Relative changes in RP node size & 20.36 & $9.62-43.13$ & $<0.0005$ \\
\hline
\end{tabular}

Table 5. Multivariate bootstrap model predicting teratoma at PC-RPLA

\section{Discussion}

ATeratomatous elements are present in the retroperitoneum in 51\% of men undergoing PC-RPLA for metastatic NSTT. Therefore, predicting its presence and implementing appropriatetherapy remains important. Despite the histologically benign nature of teratoma, there are significant advantages to complete resection. First, teratoma may grow, obstruct or invade adjacent structures and became unresectable. Second, there is the risk of malignant transformation to nongerm cell malignant elements such as sarcoma or adenocarcinoma. The incidence of malignant transformation is approximately $3 \%$ to $6 \%$ in men undergoing PC-RPLA and in those with late relapse 15,16 . Complete surgical resection is the treatment of choice for this group of chemoand radioresistante tumors 15 . Lastly, teratoma may result in devastating late relapse. Late relapse beyond 2 years of primary treatment occurs in approximately $2 \%$ to $3 \%$ of patients with testicular cancer and has been shown to occur across all stages $10,16,17$. The most common anatomical site of relapse is the retroperitoneum followed by the lungs and mediastinum. The primary management for late relapse is complete surgical resection, and histological distribution reveals viable carcinoma in $80 \%$ and teratomatous elements in $20 \%$. The overall prognosis for patients with late relapse of NSTT is relatively poor with survival rate of approximately $30 \%$ to $40 \%$. Teratoma in the orchiectomy specimen has been shown to poredict teratoma in the retroperitoneum in men with low and high volume retroperitoneal disease 18,19,20. However, the absence of teratoma in the primary tumor does not exclude the finding of teratoma in the retroperitoneum. The Indiana group reported that $82 \%$ of men with teratoma in the orchiectomy specimen undergoing PC-RPLA will have teratoma in the retroperitoneum compared to approximatelly $41 \%$ of men without teratoma in the orchiectomy specimen 18 . Previously, Beck et al reported that teratoma in the orchiectomy specimen and volume of the retroperitoneal metastasis were significant predictors for teratoma in the retroperitoneum 20. However, for patients without teratoma in the orchiectomy specimen, retroperitoneal nodal size before and after chemotherapy did not discriminate between those with and without teratoma in the retroperitoneum (approximately $50 \%$ of patients had teratoma in the retroperitoneum). In our series teratoma was found in the retroperitoneum in $62 \%$ of men with teratoma in the orchiectomy specimen and in $34 \%$ of men without teratoma in the orchiectomy specimen. Relative change in retroperitoneal nodal size before and after chemotherapy was independent predictor of teratoma in the retroperitoneum for all patients in our series, including those without teratoma in the orchiectomy specimen. 
To minimize treatment related morbidity a number of investigators have attempted to identify patients with NSTT in whom PC-RPLA may be safely omitted 6,13,21. The decision to perform PC-RPLA has been largely based on the radiological size of the residual retroperitoneal mass with recommendation to omit surgery in patients with residual masses measuring $1 \mathrm{~cm}$ or less 14,22. Donohue et al reported on men undergoing PCRPLA with no teratoma in the primary orchiectomy specimen and a greater than $90 \%$ volume reduction in retroperitoneal metastasis 21 . None of the 15 patients in this series had teratoma or viable carcinoma in the resection specimen. They concluded that PC-RPLA may safely be omitted in these patients. However, in a subsequent analysis at the same institution $74 \%$ of patients with these same criteria were continously free of disease 18. Data from various series demonstrated that $20 \%$ to $30 \%$ of patients meeting the criteria outlined by Donohue et al will have teratoma in the retroperitoneum following treatment with chemotherapy 11,12 . While greater relative change in the retroperitoneal nodal size following chemotherapy was significantly associated with a decreasing incidence of teratoma in retroperitoneum, $7(8 \%)$ of 82 patients in our series with a greater than $90 \%$ reduction in retroperitoneal nodal size had teratoma in the retroperitoneum at PC-RPLA. For men with an increasing retroperitoneal mass following chemotherapy, 16 (19\%) of 82 had teratoma in retroperitoneum indicative of growing teratoma syndrome.

On multivariate analysis, teratoma in the orchiectomy specimen, relative change in nodal size before and after chemotherapy, and no requirement for salvage chemotherapy were independent predictors of the presence of teratoma in the retroperitoneum. Combining multiple preoperative predictive variables has enhanced our ability to predict the probability of teratoma in the retroperitoneum after chemotherapy for metastatic NSTT.

We have demonstrated that multipelclinical variables are predictive in the histologic finding of teratoma in the retroperitoneum. Therefore, the combination of multiple independent predictors should be used to identify patients at risk of teratoma in the retroperitoneum following chemotherapy for metastatic NSTT.

\section{Conclusions}

Retroperitoneal teratoma is found in $51 \%$ of men with metastatic NSTT submitted to PC-RPLA. Wehave identified pre-RPLA significant variables predictive of teratoma including teratoma in theprimary tumor, relative changes in nodal size before and after chemotherapy, and no requirement for 2 nd line chemotherapy. The proper incorporation of multiple predictive clinical variables should be used to identify patients at risk for teratoma in the retroperitoneum after chemotherapy for advanced NSTT.

\section{Acknowledgments}

We cordially thank to Natalija Šeparović from Hypo Alpe Adria, Hypo facilities servicies, Belgrade, Serbia and to Mirjana Radenković, Belgrade, Serbia for technical assistance in realisation of this manuscript.

\section{Literature}

1. Sheinfeld J, Herr HW. Role of surgery in management of germ cell tumors. Semin Oncol 1998; 25:203-9.

2. Argirović $\mathrm{Dj}$, Argirović A. Pathologic findings and clinical outcome in patients undergoing retroperitoneallymphadenectomy after multiple chemotherapy regimens for metastatic non-seminomatous testicular tumors. Materia Medica 2011; 27:195:202.

3. Argirovic D, Stanic V, Argirovic A. Recurrences in nonseminomatous testicular tumors with no viable cancer at postchemotherapy retroperitoneal lymphadenectomy. Eur Urol Suppl 2010; 9:237.

4. Argirovic D, Argirovic A, Stanic V. The impact of extra-retroperitoneal masses in patients with advanced nonseminomatous testicular tumors. Eur Urol Suppl 2010; 9: 239.

5. Toner GC, Panicek DM, Heelan RT, Geller NL, Lin SY, Bajorin D, et al. Adjunctive surgery after chemotherapy for nonseminomatous germ cell tumors: recommendationfor patients selection. J Clin Oncol 1990; 8:1683-94.

6. Steyeberg EW, Keizer HJ, Fossa SD, Slejfer DT, Toner GC, Schraford Kopps H, et al. Prediction of residual retroperitoneal mass histology after chemotherapy for metastatic nonseminomatous germ cell tumors: multivariate analysis of individual patient data from six study groups. J Clin Oncol 1995; 13:1177-87. 
7. Argirović Dj, Argirović A. Pure testicular teratoma in adults: experience in the treatment of 49 conssecutive cases. Materia Medica 2011; 27:221-7.

8. Argirovic D, Argirovic A. Long term outcome after postchemotherapy retroperitoneal lymphadenectomy in patients with residual teratoma. Eur Urol Suppl 2010; 9:236.

9. Argirovic D, Argirovic A. Teratoma indentified after postchemotherapy retroperitoneal lymphadenectomy. Materia Medica 2013; 29:889-97.

10. Argirovic D. Late relapses of germ cell tumors following treatment for nonseminomatous testicular tumors according to single center- based experience. Eur Urol Suppl 2007; 6:539.

11. Fossa SD, Quist H, Stenwig AE, Lien HH, Ous S, Giercksky KE. Is postchemotherapy retroperitoneal surgery necessary in patients with nonseminomatous testicular cancer and minimal residual tumor masses? J Clin Oncol 1992; 10:569-73.

12. Fossa SD, Ous S, Lien HH, Stenwig AE. Postchemotherapy lymph node histology in radiologically normal patients with metastatic nonseminomatous testicular cancer. J Urol 1989; 141:575-9.

13. Argirovic D, Argirovic A. Long term follow-up of cisplatin combination chemotherapy in patients with disseminated non-seminomatous testicular tumors: is a post-chemotherapy retroperitoneal lymphadenctomy needed after complete remission? Eur Urol Suppl 2011; 10: 319.

14. Schmoll HJ, Sonchon R, Krege S, Albers P, Beger J, Kollmannsberger C, et al. European Concensus on diagnosis and treatment of germ cell cancer: a report of the European Germ Cell Cancer Concensus Group (EG CCCG). Ann Oncol 2004; 15:1377-99.

15. Motzer RJ, Amsterdam A, Prieto V, Scheinfeld J, Murty VV, Mazumdar M, et al. Teratoma with malignant transformation: diverse malignant histologies arising in men with germ cell tumors. J Urol 1998; 159:133-8.

16. Baniel J, Foster RS, Gonin R, et al. Late relapses of testicular cncer. J Clin Oncol 1995, 13:1170-6.

17. Dieckmann KP, Albers P, Classen J, De Witt M, Pichlmeir U, Rick O, et al. Late relapses of testicular germ cell neoplasms: a descriptive analysis of 122 cases. J Urol 2005; 173:824-9.

18. Debono DJ, Heilman DK, Einhorn 1H, Donohue JP. Decision analysis for avoiding postchemotherapy surgery in patients with disseminated nonseminomatous germ cell tumors. J Clin Oncol 1997; 15:1455-64.

19. Rabbani F, Gleare ME, Chopin CM, Murray N, Sullivan LD. Teratoma in primary testis tumor reduces complete response rates in the retroperitoneum after primary chemotherapy. The case for primary retroperitoneal lymph node dissection of stage IIb germ cell tumors with teratomatous elements. Cancer 1996: 78:480-6.

20. Beck SD, Foster RS, Bihrle R, Ulbright T, Koch MO, Wahle GR, et al. Teratoma in the orchietomy specimen and volume of metastasis are predictors of retroperitoneal teratoma in post-chemotherapy nonseminomatous testis cancer. J Urol 2002; 168:1402-4.

21. Donohue JP, Rowland RG, Kopecky K, Steidle CP, Geier G, Ney KG, et al. Correlation of computerized tomography changes and histological findings in 80 patients having radical retroperitoneal lymph node dissection after chemotherapy for testis cancer. J Urol 1987, 137:1176-9.

22. Pfister D, Busch J, Schrader M, Winter C, Albers P, Dieckmann KP, et al. Pathohistological findings in patients with nonseminomatous germ cell tumours who undergo post-chemotherapy retroperitoneal lymph node dissection for small tumors. Eur Urol Supp 2011; 19:319.

Corresponding author:

Djordje Argirović, Outpatient Clinic „Argirović“, Urology Cvijićeva 84 A, 11120 Belgrade, Serbia Tel. : + 381112788498,2787900

Fax.: + 381113290324

E-mail: djordje.argirovic@gmail.com 